\title{
UI AKTIVITAS ANTIKANKER PAYUDARA SENYAWA ANDROGRAFOLIDA DARI TUMBUHAN SAMBILOTO (Andrographis paniculata (Burm F) Ness.) TERHADAP HUMAN EPIDERMAL GROWTH FACTOR RECEPTOR 2 (HER-2) SECARA IN SILICO
}

\author{
Sintya Suherlan*, Rohayah, Taufik Muhammad Fakih \\ Program Studi Farmasi, Fakultas Matematika dan IImu Pengetahuan Alam, Universitas Islam Bandung \\ Jl. Rangga Gading No. 8, Bandung 40116, Indonesia
}

\section{Info Article}

\section{Submitted :}

25 Maret 2021

\section{Revised :}

27 April 2021

Accepted :

08 Juli 2021

\section{Corresponding Author :}

Sintya Suherlan

\section{Email :}

sintyasuherlan26@gmail.com

\section{ABSTRAK}

Kanker payudara merupakan suatu keadaan dimana sel telah kehilangan pengendalian dan mekanisme normalnya, sehingga terjadi pertumbuhan yang tidak normal, cepat, dan tidak terkendali pada jaringan payudara. Kanker payudara dapat menyebabkan kematian pada kaum wanita. Andrographolide merupakan salah satu senyawa antikanker yang terkandung pada tanaman sambiloto (Andrographis Paniculata (Burm F) Ness.). Adapun reseptor Human Epidermal Growth Factor Receptor 2 (HER-2) merupakan resepor yang memiliki peranan penting pada kanker payudara. Tujuan pada peneitian ini adalah untuk mengetahui afinitas dan interaksi antara senyawa Andrographolide dan Dendronpholide G dengan reseptor HER-2 secara in silico. Pada penelitian ini dilakukan identifikasi sifat fisikokimia senyawa Andrographolide dan Dendronpholide $\mathrm{G}$ dengan menggunakan server swiss-ADME. Kemudian senyawa tersebut dioptimasi menggunakan software Avogadro. Setelah mendapatkan konformasi senyawa uji terbaik kemudian dilakukan tahap selanjutnya yaitu simulasi molecular docking menggunakan reseptor HER-2 terhadap senyawa uji menggunakan software MGL Tools 1.5.6 yang dilengkapi Autodock Tools 4.2. Adapun hasil penelitian yang diperoleh yaitu interaksi yang terjadi pada senyawa uji Andrographolide menghasilkan energi bebas ikatan sebesar $-5,42 \mathrm{Kcal} / \mathrm{mol}$ dan nilai konstanta inhibisi 105,72 nM, sedangkan Dendranpholide G menghasilkan energi bebas ikatan sebesar $-3,67 \mathrm{Kcal} / \mathrm{mol}$ dan nilai konstanta inhibisi 2,05 $\mu \mathrm{M}$. Interaksi pada senyawa Andrographolide dan Dendranpholide $G$ dengan reseptor HER-2 yaitu 1 ikatan hidrogen (MET801) dan terdapat 4 interaksi hidrofobik (MET801, LEU726, ALA751, LEU852). Hasil dari simulasi molecular docking dapat diprediksi bahwa senyawa Andrographolide memiliki afinitas yang baik dibandingkan senyawa Dendranpholide G maka dapat dinyatakan sebagai kandidat antikanker payudara.

Kata kunci: Kanker Payudara, Andrographolide, Dendronpholide G, Human Epidermal Growth Factor Receptor 2 (HER-2), Molecular Docking.

Access this article

\section{ABSTRACT}

Breast cancer is a condition in which cells have lost their normal control and mechanism, resulting in abnormal, rapid, and uncontrolled growth in breast tissue. Breast cancer can cause death in women. Andrographolide is one of the anticancer compounds contained in the bitter plant 


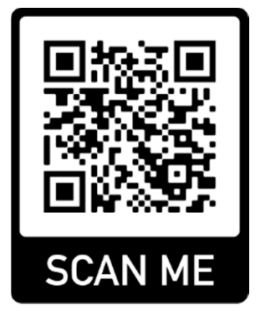

(Andrographis Paniculata (Burm F) Ness.). The Human Epidermal Growth Factor Receptor 2 (HER-2) receptor is a receptor that has an important role in breast cancer. The purpose of this study was to determine the affinity and interaction between Andrographolide and Dendronpholide G compounds with HER-2 receptors in silico. In this study, identification of the physicochemical properties of Andrographolide and Dendronpholide $G$ compounds was carried out using the Swiss-ADME server. Then the compound is optimized using Avogadro software. After obtaining the best conformation of the test compound, the next step was performed, namely, molecular docking simulation using the HER-2 receptor for the test compound using MGL Tools 1.5.6 software with Autodock Tools 4.2. The research results obtained are interactions that occur in the Andrographolide test compound producing binding free energy of -5.42 $\mathrm{Kcal} / \mathrm{mol}$ and an inhibition constant value of $105.72 \mathrm{nM}$, while Dendranpholide $\mathrm{G}$ produces binding free energy of $-3.67 \mathrm{Kcal} / \mathrm{mol}$ and the value of the inhibition constant was $2.05 \mathrm{M}$. The interaction of Andrographolide and Dendranpholide G with HER-2 receptors is 1 hydrogen bond (MET801) and there are 4 hydrophobic interactions (MET801, LEU726, ALA751, LEU852). The results of the molecular docking simulation can be predicted that the Andrographolide compound has a good affinity compared to the Dendranpholide $\mathrm{G}$ compound so it can be declared as an anticancer candidate for breast.

Keywords: Breast Cancer, Andrographolide, Dendronpholide G, Human Epidermal Growth Factor Receptor 2 (HER-2), Molecular Docking.

\section{PENDAHULUAN}

Salah satu penyebab kematian utama di dunia adalah penyakit kanker. Kanker adalah penyakit yang disebabkan oleh sel abnormal jaringan tubuh yang tumbuh dan berkembang dengan cepat serta tak terkendali, menekan jaringan tubuh sehingga mempengaruhi organ tubuh. Diperkirakan kematian akibat kanker di dunia mencapai 4,3 juta per tahun dan 2,3 juta diantaranya ditemukan di negara berkembang, jumlah penderita baru per tahun 5,9 juta di seluruh dunia dan tiga juta diantaranya ditemukan di negara yang sedang berkembang (Day et al., 2021). Terdapat berbagai jenis kanker salah satunya adalah kanker payudara. Kanker payudara merupakan pertumbuhan abnormal sel jaringan payudara, ketika selsel di dalam kelenjar payudara mulai tumbuh dan berkembang tidak terkontrol (BP Basuki, 2015; Haslam \& Prasad, 2019).
Salah satu reseptor yang dapat digunakan sebagai target pada kanker payudara adalah protein Human Epidermal Growth Factor Receptor 2 (HER-2) (Yoshimoto et al., 2020). Invasi sel kanker dapat terjadi akibat ekspresi berlebih protein HER-2. Ekspresi berlebih protein HER-2 mampu menginduksi terjadinya proses migrasi dan metastasis sel kanker melalui induksi dimerisasi secara spontan, autofosforilasi, dan terjadinya aktivasi Focal Adhesion Kinase (FAK) (Berdan et al., 2019).

Terapi yang digunakan untuk penyakit kanker yaitu dengan obat spesialistik namun dapat memberikan efek samping. Selain itu, obat tersebut juga dapat menyebabkan kematian dengan langsung maupun tidak langsung. Obat antikanker dapat bekerja pada sel yang aktif di bagian jaringan pada sistem hemopoetik dan gastrointestinal (Johnson et al., 2010). 
Beberapa penemuan obat antikanker mengarah pada pencarian senyawa aktif yang dapat menghambat pertumbuhan. Andrographolide merupakan salah satu senyawa aktif atau metabolit sekunder yang memiliki aktivitas antikanker dan terkandung pada tanaman sambiloto (Andrographis paniculata (Burm F) Ness.) yang termasuk diterpen lakton ( $\mathrm{Li}$ et al., 2017).

Tanaman sambiloto memiliki manfaat untuk pengobatan dan telah banyak digunakan oleh masyarakat Indonesia untuk berbagai macam penyakit serta memiliki aktivitas farmakologi untuk antikanker. Senyawa Andrographolide dan Dendronpholide $G$ merupakan senyawa yang memiliki aktivitas antikanker dengan mekanisme menghambat NF-Kb yaitu pada DNA yang mampu meningkatkan Tumor Necrosis Factor Alfa yang dapat mengapoptosis (Motaparthi et al., 2014).

Pada penelitian ini digunakan studi in silico yaitu metode molecular docking untuk memprediksi bagaimana protein HER-2 berinteraksi dengan senyawa aktif Andrographolide dan Dendronpholide G. Penelitian ini penting untuk mengetahui bagaimana afinitas dan mekanisme interaksi molekular antara senyawa uji terhadap protein target.

\section{METODE PENELITIAN}

\subsection{Alat}

Alat yang digunakan pada penelitian ini yaitu perangkat keras berupa laptop tipe HP dengan spesifikasi RAM $8 \mathrm{~GB}$, processor intel Core 7th Gen core i7-7500U 2,70 GHz (4 CpUs) $2.9 \mathrm{GHz}$, Storage 1TB, Display 14" (1920*1080) Graphic Intel Radeon, Windows 10 yang dilengkapi dengan beberapa software yaitu Swiss-ADME, Avogadro,
Toxtree 3.1.0, HyperChem Professional 8.0, MGL Tools 1.5.6 yang telah dilengkapi dengan AutoDock Tools 4.2, dan BIOVIA Discovery Studi 2019.

\subsection{Bahan}

Bahan pada penelitian ini yaitu stuktur dua dimensi (2D) senyawa Andrographolide dan Dendronpholide $G$ yang diunduh pada website Pubchem. Sruktur makromolekul reseptor Human Epidermal Growth Factor Receptor 2 (HER-2) yang diunduh pada website Protein Data Bank (PDB) dengan kode 3PP0 (Aertgeerts et al., 2011).

\subsection{Prosedur}

\subsubsection{Identifikasi Sifat Fisikokimia Senyawa Uji}

Identifikasi sifat fisikokimia dilakukan dengan menggunakan server Swiss-ADME terhadap senyawa Andrographolide dan Dendronpholide G. Tujuan dilakukan identifikasi ini untuk mengetahui sifat farmakologi dan farmakokinetika dari senyawa uji dan untuk mengetahui apakah senyawa Andrographolide dan Dendronpholide $\mathrm{G}$ memenuhi persyaratan aturan lipinski rule of five. Beberapa aturan lipinski diantaranya suatu senyawa harus memiliki massa molekul kurang dari 500 dalton, memiliki lipofisilitas yang tinggi (dinyatakan dengan log $\mathrm{p}$ tidak lebih dari 5), donor ikatan hidrogen tidak lebih dari 5, dan akseptor ikatan hidrogen tidak lebih dari 10 (Chen et al., 2020).

\subsubsection{Prediksi Toksisitas Senyawa Uji}

Pada tahap ini dilakukan prediksi toksisitas senyawa Andrographolide dan Dendronpholide $G$ dengan menggunakan software Toxtree 3.1.0. Prediksi toksisitas tersebut bertujuan untuk melihat paramater Cramer Rulesyaitu untuk melihat 
tingkat toksisitas dari gugus fungsinya. Kroes TCC digunakan untuk memperkirakan ambang batas paparan senyawa obat pada manusia. Carcinogenicity and Mutagenicity untuk mengetahui apakah senyawa tersebut negative genotoxic dan non negative genotoxic (Hirota et al., 2018).

\subsubsection{Optimasi Geometri Senyawa Uji}

Tahap optimasi geometri senyawa Andrographolide dan Dendronpholide G dilakukan dengan menggunakan software HyperChem Professional 8.0. Optimasi geometri ini bertujuan untuk memperoleh konfirmasi stuktur yang sebenarnya dengan metode semi empiris AM1 (Wang et al., 2020).

\subsubsection{Preparasi Struktur Makromolekul}

Pengunduhan makromolekul reseptor Human Epidermal Growth Factor Receptor 2 (HER-2) yang akan digunakan sebagai target pada proses molecular docking diunduh melalui website Protein Data Bank (PDB) dengan kode 3PP0. Makromolekul reseptor ini akan digunakan pada tahap selanjutnya untuk validasi metode docking (Priani \& Fakih, 2021).

\subsubsection{Validasi Metode Docking}

Validasi metode docking dilakukan menggunakan reseptor yang sebelumnya telah diunduh. Validasi metode docking dilakukan menggunakan software MGL Tools 1.5.6 yang telah dilengkapi dengan AutoDock Tools 4.2. Reseptor HER-2 dipilih ligan alaminya untuk dilakukan proses validasi metode docking. Parameter validasi metode adalah nilai Root Mean Square Deviation (RMSD). Sebuah validasi metode docking dinyatakan valid dan dapat digunakan jika RMSD-nya < $2 \AA$ (Ramadhan et al., 2020).

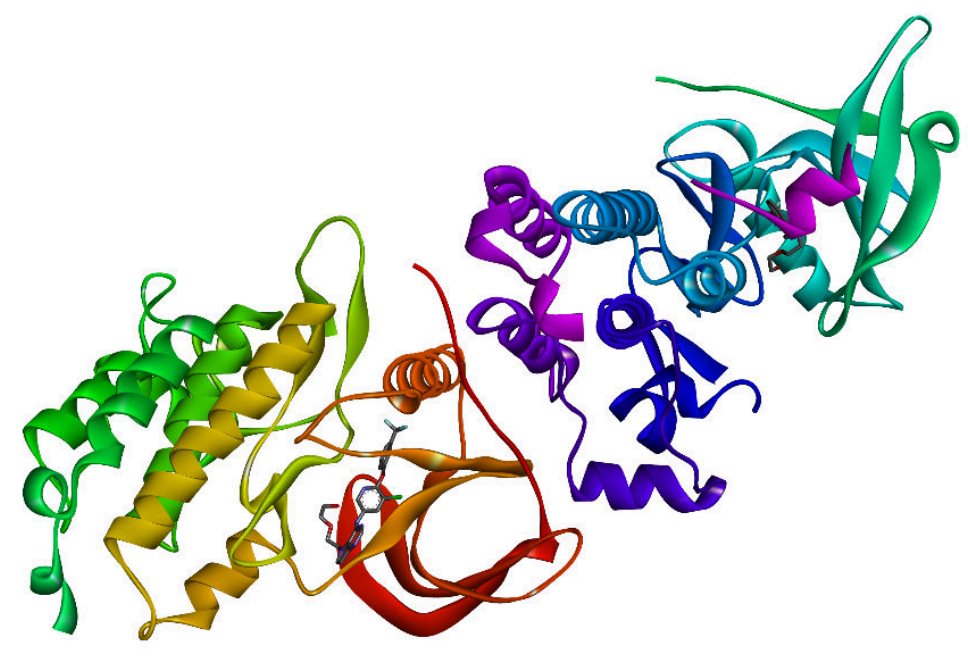

Gambar 2. Struktur Tiga Dimensi Makromolekul Human Epidermal Growth Factor Receptor 2 (HER-2).

\subsubsection{Simulasi Molecular Docking}

Simulasi molecular docking dilakukan antara reseptor HER-2 dengan senyawa Andrographolide dan Dendronpholide G menggunakan software MGL Tools 1.5.6 yang telah dilengkapi dengan AutoDock Tools 4.2. Simulasi docking ini dilakukan untuk memprediksikan pengikatan dari molekul-molekul kecil untuk mengetahui struktur target dan untuk membandingkan senyawa uji yang memiliki energi ikatan $(\Delta \mathrm{G})$ dan konstanta inhibisi (Ki) yang baik (Qasaymeh et al., 2019). 


\subsubsection{Analisis Hasil Molecular Docking}

Hasil molecular docking kemudian dianalisis dengan menggunakan software BIOVIA Discovery Studio 2019. Analisis data dari hasil docking ini pada sisi binding site reseptor HER-2 dengan melihat interaksi molekular yang terbentuk (Kemmish et al., 2017).

\section{HASIL DAN PEMBAHASAN}

\subsection{Identifikasi Sifat Fisikokimia Senyawa Uji}

Penelitian ini dilakukan dengan penentuan parameter sifat fisikokimia senyawa Andrographolide dan Dendronpholide $\mathrm{G}$ dengan menggunakan server Swiss-ADME (Mahanthesh et al., 2020). Pada sifat fisikokimia ada yang perlu diperhatikan yaitu lipofilitas, refraktifitas molar, dan bobot molekul yang menjadi parameter uji. Tujuan dilakukan tahapan ini yaitu untuk mengetahui daya penembusan membran biologis pada senyawa Andrographolide dan Dendronpholide G.

Tabel 1. Hasil Identifikasi Karakteristik Sifat Fisikokimia Senyawa Uji.

\begin{tabular}{clcc}
\hline No & \multicolumn{1}{c}{ Parameter } & Andrographolide & Dendronpholide G \\
\hline 1 & Berat Molekul & $350,45 \mathrm{~g} / \mathrm{mol}$ & $424,53 \mathrm{~g} / \mathrm{mol}$ \\
2 & Jumlah Akseptor Ikatan Hidrogen & 5 & 5 \\
3 & Jumlah Donor lkatan Hidrogen & 3 & 7 \\
& & 95,21 & 111,87 \\
4 & Refraktivitas Molar & 2,61 & 3.83 \\
5 & Log P & $-3,18$ & $-3,69$ \\
6 & Log S & Yes; 1 violation: & Yes; 0 violation: MW $>500$ \\
& Lipinski & MW $>500$ & \\
\hline
\end{tabular}

Parameter sifat fisikokimia senyawa uji harus memenuhi aturan lipinski rule of five. Pada Tabel 1, parameter sifat fisikokimia senyawa Andrographolide dan Dendronpholide $G$ dapat dinyatakan memenuhi persyaratan aturan lipinski rule of five karena hasil yang didapat bobot molekul pada Andrographolide yaitu 350,45 $\mathrm{g} / \mathrm{mol}$ dan Dendronpholide $\mathrm{G}$ yaitu 424,53 $\mathrm{g} / \mathrm{mol}$ maka kedua senyawa tersebut dapat berdifusi menembus membran dengan baik dimana kedua senyawa tersebut sesuai aturan lipinski yaitu kurang dari $500 \mathrm{~g} / \mathrm{mol}$ (Benet et al., 2016). Semakin besar bobot molekul yang diperoleh maka semakin buruk kemampuan dalam berdifusi menembus membran. Dendronpholide G merupakan senyawa yang kurang baik dalam kemampuan difusi membran biologis karena bobotnya lebih besar dibandingkan Andrographolide.

Kemudian jumlah ikatan akseptor pada senyawa Andrographolide memiliki jumlah akseptor ikatan hidrogen 5 dan Dendranpholide $G$ jumlah akseptor ikatan hidrogen 5 maka kedua senyawa tersebut memenuhi aturan lipinskikarena hasil yang didapat yaitu 5. Jumlah donor ikatan hidrogen Andrographolide yaitu 3 dan Dendranpholide $G$ memiliki jumlah donor ikatan hidrogen yaitu 7 yang merupakan sesuai dengan aturan lipinskikarena kurang dari 10.

Parameter lipofilitas yaitu koefisien parsisi (Log P) dan C log P. Parameter ini menyatakan keseimbangan pada nilai 
lipofilitas senyawa yang membandingkan kelarutan senyawa pada pelarut polar dan non polar (Tanbin et al., 2021). Lipofilitas merupakan sifat yang berhubungan dengan proses absrobsi suatu obat. Semakin tinggi hasil nilai log $P$ maka semakin tinggi kemampuan lipofilitas dalam menembus membran. Maka pada penelitian ini $C \log P$ yang didapat pada senyawa Andrographolide yaitu 2,61 dan Dendranpholide $\mathrm{G}$ didapat yaitu 3,83 maka pada kedua senyawa tersebut memberikan hasil yang baik karena kurang dari 5. Apabila nilai $C \log P$ semakin tinggi maka akan semakin hidrofobik yang menyatakan bahwa senyawa tersebut kurang baik (Petit et al., 2012).

Kemudian refraksi molar (MR) yaitu ukuran molar pada molekul senyawa. Nilai Calculated Molar Refraction (CMR) yaitu kalkulasi reflaksi molar. Refraktivitas molar digunakan untuk menyatakan sifat sterik suatu senyawa yang dapat mempengaruhi interaksi obat terhadap reseptor. Semakin besar hasil CMR maka semakin besar sifat sterik yang didapatkan, maka interaksi obat terhadap reseptor kurang baik (Gyebi et al., 2021). Hasil yang diperoleh pada penelitian ini CMR pada senyawa Andrographolide yaitu 95,21 dan Dendranpholide G yaitu 111,87 maka hasil yang diperoleh dari kedua senyawa tersebut dinyatakan baik karena memenuhi persyaratan lipinski rule of five yaitu 40-130. Nilai CMR yang didapat pada senyawa Andrographolide memiliki nilai CMR yang lebih kecil dibandingkan Dendronpholide G, maka menunjukan bahwa senyawa andrographolide memiliki sifat hidrofobik dimana efek dari hidrofobik yang mempermudah senyawa berikatan dengan reseptor.

\subsection{Prediksi Toksisitas Senyawa Uji}

Pada tahap selanjutnya yaitu prediksi toksisitas senyawa uji Andrographolide dan Dendranpholide G. Prediksi toksisitas bertujuan untuk mengetahui parameter dari Cramer Rules yang digunakan untuk mengetahui kelas berapa tingkat toksisitas yang dilihat dari gugus fungsinya, kemudian Kroes TTC digunakan untuk mengetahui ambang batas paparan senyawa obat manusia, dan Carcinogenetiy and Mutagenity untuk mengetahui senyawa uji memiliki efek karsinogenisitas dan mutagenisitas dengan menggunakan software Toxtree 3.1.0.

Tabel 2. Hasil Prediksi Toksisitas Senyawa Uji.

\begin{tabular}{cccc}
\hline No & Parameter & Andrographolide & Dendronpholide G \\
\hline 1 & Cramer Rules & High (Class III) & High (Class III) \\
2 & Kroes TTC & $\begin{array}{c}\text { Substance would not be } \\
\text { expected to be a safety } \\
\text { concern }\end{array}$ & $\begin{array}{c}\text { Substance would not be expected } \\
\text { to be a safety concern }\end{array}$ \\
3 & $\begin{array}{c}\text { Carcinogenicity and } \\
\text { Mutagenicity }\end{array}$ & $\begin{array}{c}\text { Negative for genotoxic } \\
\text { carcinogenicity and negative } \\
\text { for nongenotoxic } \\
\text { carcinogenicity }\end{array}$ & $\begin{array}{c}\text { Negative for genotoxic } \\
\text { carcinogenicity and negative for } \\
\text { nongenotoxic carcinogenicity }\end{array}$ \\
\hline
\end{tabular}


Adapun hasil yang diperoleh pada Tabel 2 menunjukkan bahwa senyawa Andrographolide dan Dendragpholide termasuk dalam kelas III yang artinya termasuk kedalam toksisitas yang tinggi. Selanjutnya Kroes TTC yang didapat pada senyawa Andrographolide dan Dendranpholide $G$ berada pada ambang batas paparan dengan resiko rendah. Carcinogenetiy and Mutagenity dihasilkan pada senyawa Andrographolide dan
Dendranpholide G menghasilkan hasil negative yang berarti tidak terpapar senyawa karsinogenik dan mutagenik.

\subsection{Optimasi Geometri Senyawa Uji}

Selanjutnya dilakukan optimasi geometri pada senyawa Andrographolide dan Dendranpholide G. Adapun tujuannya untuk menghasilkan konformasi stuktur yang paling stabil (Fakih et al., 2021).

Tabel 3. Total Energi Senyawa Uji.

\begin{tabular}{ccc}
\hline No & Nama Senyawa & Total Energi \\
\hline 1 & Andrographolide & $391,67 \mathrm{~kJ} / \mathrm{mol}$ \\
2 & Dendranpholide G & $355,162 \mathrm{~kJ} / \mathrm{mol}$ \\
\hline
\end{tabular}

Hasil yang diperoleh dalam Tabel $\mathbf{3}$ menyatakan nilai energi total pada senyawa Andrographolide $391,67 \mathrm{~kJ} / \mathrm{mol}$ dan Dendranpholide G yaitu 355, 162 kJ/mol. Jika energi total semakin rendah maka konformasi stuktur stabil, maka senyawa Dendranpholide $G$ memiliki nilai energi total yang paling stabil dibandingkan Andrographolide.

\subsection{Preparasi Struktur Makromolekul}

Dilakukan tahap preparasi stuktur makromolekul reseptor Human Epidermal Growth Factor Receptor 2 (HER-2) yang diunduh pada website Protein Data Bank (PDB), dengan kode 3PP0 untuk dilakukan tahap selanjutnya yaitu validasi metode docking. Kemudian dilakukan penghapusan molekul air supaya tidak menganggu saat proses validasi docking, dan dipisahkan reseptor HER-2 dengan ligan alami yang digunakan untuk mempermudah proses docking. Kemudian ditambahkan muatan parsial untuk dijadikan muatan yang netral.

\subsection{Validasi Metode Docking}

Dilakukan tahap validasi metode docking dengan mengamati nilai Root Mean Square Deviation (RMSD). Tahap ini memiliki tujuan untuk mendapatkan metode yang cocok pada tahap simulasi molecular docking. Reseptor HER-2 dipilih ligan alaminya untuk proses validasi docking. Didapat nilai RMSD kurang dari $2 \AA$, maka dinyatakan metode docking telah valid. Parameter yang dilihat yaitu ukuran grid box, jumlah konformasi, dan nilai maksimum evaluasi pencarian konformasi (short, medium, long). 
Tabel 4. Hasil Validasi Metode Docking.

\begin{tabular}{ccc}
\hline No & Parameter & Hasil \\
\hline 1 & Ukuran Grid BoX & $\mathrm{X}: 64 ; \mathrm{Y}: 60 ; \mathrm{Z}: 60$ \\
2 & Spacing & $0.375 \AA$ \\
3 & Grid Center & $\mathrm{X}:-14,715 ; \mathrm{Y}: 6,648 ; \mathrm{Z}:-31,686$ \\
4 & RMSD & $1,41 \AA$ \\
5 & Binding Energi Ligand Alami & $-9,7 \mathrm{kcal} / \mathrm{mol}$ \\
6 & Konstanta Inhibisi & $77,73 \mu \mathrm{M}($ micromolar $)$ \\
\hline
\end{tabular}

Parameter validasi metode docking dipilih yaitu jumlah pencarian konformasi sebanyak 10 (short), ukuran grid box yang digunakan harus dapat menutupi seluruh bagian senyawa ligan alami dan senyawa uji agar diperoleh hasil yang baik yaitu $(64 \times 60 \times 60)$ dengan menggunakan software MGL Tools 1.5.6 yang telah dilengkapi Autodock Tools 4.2. Ukuran grid centeryaitu $(x, y, z)(-14,715 ; 6,648 ;-31,686)$ dan spacing $0,375 \AA$. Koordinat pada $(x, y, z)$ akan digunakan pada tahap simulasi molecular docking senyawa uji.

Adapun hasil yang didapat pada Tabel 4, validasi metode docking dengan ligan alami hasilnya diperoleh nilai RMSD pada binding site reseptor HER-2 yaitu sebesar 1,41 A. Maka nilai yang didapat memenuhi syarat jika nilai RMSD kurang dari $2 \AA$ maka metode docking memenuhi persyaratan. Semakin kecil nilai RMSD yang diperoleh maka semakin mendekati posisi ligan alaminya (Kontoyianni et al., 2004).

\subsection{Simulasi Molecular Docking}

Pada tahap simulasi molecular docking antara reseptor HER-2 dengan senyawa Andrographolide dan Dendranpholide $G$ pada ukuran grid box dan koordinat disaat validasi metode docking. Docking merupakan terjadinya interaksi penambatan ligan dengan protein yang dipakai dalam prediksi orientasi ligan terikat dengan reseptor. Pada hasil docking didapat energi bebas ikatan $(\Delta \mathrm{G})$ dan konstanta inhibisi (Ki) yang menjadi parameter kestabilan konformasi ligan dengan reseptor. Reseptor dan ligan dapat berinteraksi pada kondisi energi yang rendah, karena dapat menyababkan keadaan menjadi stabil. Semakin kecil energi ikatan maka interaksi ligan dan reseptor akan stabil (Darusman et al., 2021).

Tabel 5. Hasil Simulasi Molecular Docking Senyawa Uji.

\begin{tabular}{cccc}
\hline No & Nama Senyawa & Binding Energi & Konstanta Inhibisi \\
\hline 1 & Andrographolide & $-5,42 \mathrm{Kcal} / \mathrm{mol}$ & $105,72 \mathrm{nM}$ \\
2 & Dendronpholide G & $-3,67 \mathrm{Kcal} / \mathrm{mol}$ & $2,05 \mu \mathrm{M}$ \\
\hline
\end{tabular}

Adapun hasil yang diperoleh pada Tabel 5 yaitu energi bebas ikatan senyawa Andrographolide $-5,42 \mathrm{Kcal} / \mathrm{mol}$ dan Dendranpholide $\mathrm{G}$ yaitu $-3,67 \mathrm{Kcal} / \mathrm{mol}$, maka hasil yang diperoleh kedua senyawa uji menunjukan afinitas yang baik. Dari kedua senyawa tersebut senyawa Andrographolide menunjukan nilai energi 
bebas ikatan yang paling besar maka memiliki ikatan yang kuat dengan reseptor HER-2 dan stabil dibandingkan Dendranpholide G. Kemudian jika dilihat dari konstanta inhibisi hasil yang sangat rendah yaitu Andrographolide 105,72 nM dibandingkan Dendranpholide G 2,05 $\mu \mathrm{M}$. Semakin rendah nilai konstanta inhibisi maka aktivitas penghambatanya semakin efektif dan baik, maka Andrographolide memiliki konstanta inhibisi yang semakin kuat dan stabil terhadap reseptor HER-2 dibandingkan Dendranpholide G.

\subsection{Analisis Hasil Molecular Docking}

Dilakukan Dilakukan analisis hasil molecular docking senyawa andrographolide dan dendranpholide G dengan reseptor HER-2. Pengamatan dilakukan terhadap interaksi molekular residu asam amino yaitu ikatan hidrogen, interaksi hidrofobik, interaksi elektrostatik, dan jarak interaksi. Berdasarkan visualisiasi dua dimensi hasil molecular docking, senyawa Andrographolide dan Dendrandpholide G mampu menempati binding site reseptor HER2.
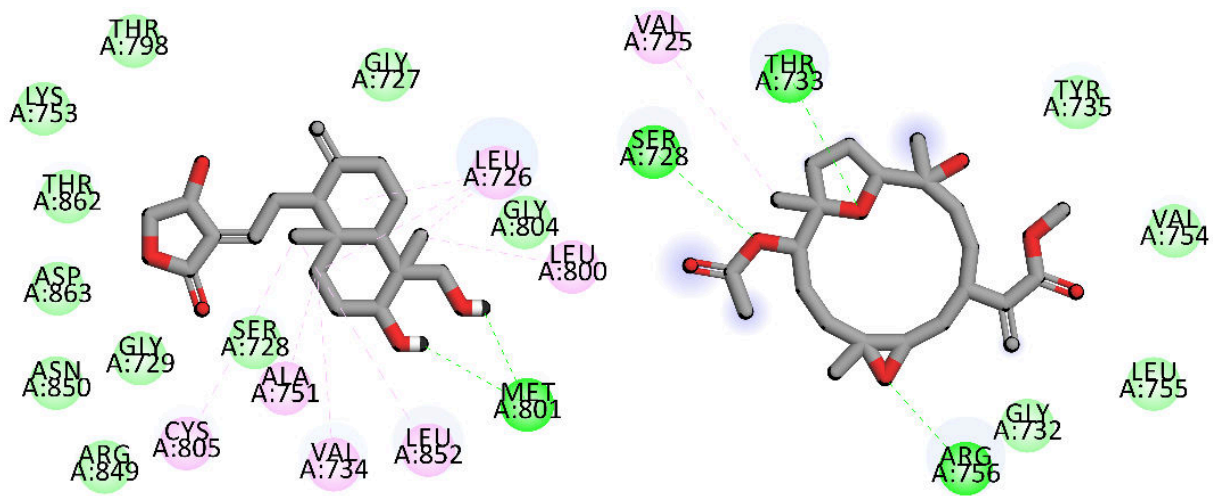

Gambar 3. Interaksi Dua Dimensi Senyawa Andrographolide (kiri) dan Dendronpholide G (kanan).

Interaksi senyawa Andrographolide area pengikatan senyawa Andrographolide dan Dendranpholide $G$ terhadap binding dan Dendranpholide $G$ terhadap reseptor site reseptor HER-2 dilakukan untuk HER-2.

mengetahui lebih jauh tentang karakteristik 
Tabel 6. Interaksi Senyawa Andrographolide (atas) dan Dendronpholide G (bawah) terhadap Reseptor HER-2.

\begin{tabular}{cccc}
\hline No & Residu Asam Amino & Jarak $(\mathbf{A})$ & Tipe Ikatan \\
\hline 1 & MET801 & 2,29486 & Ikatan Hidrogen \\
2 & MET801 & 2,38537 & Ikatan Hidrogen \\
3 & LEU726 & 3,92058 & InteraksiHidrofobik \\
4 & ALA751 & 4,12476 & InteraksiHidrofobik \\
5 & LEU726 & 4,0522 & Interaksi Hidrofobik \\
6 & VAL734 & 3,87825 & InteraksiHidrofobik \\
7 & CYS805 & 4,902 & InteraksiHidrofobik \\
8 & LEU852 & 4,0464 & Interaksi Hidrofobik \\
9 & LEU726 & 3,8535 & Interaksi Hidrofobik \\
10 & LEU800 & 4,96756 & Interaksi Hidrofobik \\
\hline 1 & SER728 & 3,27766 & Ikatan Hidrogen \\
2 & THR733 & 2,85031 & Ikatan Hidrogen \\
3 & ARG756 & 2,79138 & Ikatan Hidrogen \\
4 & TYR735 & 2,93114 & Ikatan Hidrogen \\
5 & TYR735 & 3,35988 & Ikatan Hidrogen \\
6 & VAL725 & 4,38802 & Interaksi Hidrofobik \\
\hline
\end{tabular}

Hasil dari interaksi senyawa uji pada Tabel 6 yaitu terdapat 1 ikatan hidrogen (MET801), dan terdapat 4 interaksi hidrofobik (MET801, LEU726, ALA751, LEU852). Berdasarkan hasil tersebut dapat dinyatakan senyawa Andrographolide memiliki kemiripan interaksi molekular terhadap residu asam amino dengan ligan alami yang memiliki peran sebagai penyusun binding site dari reseptor HER-2. Berdasarkan hasil molecular docking dapat dinyatakan bahwa senyawa Andrographolide merupakan senyawa yang paling baik karena memiliki ikatan residu asam amino yang lebih banyak, dimana ikatan asam amino yang lebih banyak berarti menunjukkan bahwa senyawa tersebut memiliki ikatan yang paling baik dan stabil dengan reseptor yang digunakan (Norel et al., 2008).

\section{KESIMPULAN}

Dapat disimpulkan berdasarkan penelitian, hasil molecular docking yang diperoleh dapat disimpulkan bahwa senyawa Andrographolide memiliki energi bebas ikatan $-5,42 \mathrm{Kcal} / \mathrm{mol}$ dan nilai konstanta inhibisi 105,72 nM, sedangkan Dendranpholide $G$ energi bebas ikatan $-3,67 \mathrm{Kcal} / \mathrm{mol}$ dan nilai konstanta inhibisi 2,05 $\mu \mathrm{M}$. Senyawa Andrographolide memiliki afinitas yang baik dibandingkan Dendranpholide G. Interaksi senyawa Andrographolide, Dendranpholide G, dan ligan alami pada reseptor HER-2 yaitu terdapat 1 ikatan hidrogen (MET801), dan terdapat 4 interaksi hidrofobik (MET801, LEU726, ALA751, LEU852). Dapat disimpulkan bahwa senyawa Andrographolide dapat dijadikan senyawa kandidat antikanker payudara berdasarkan simulasi molecular docking.

\section{UCAPAN TERIMA KASIH}

Penulis mengucapkan terima kasih kepada Program Studi Farmasi, Fakultas Matematika dan ilmu Pengetahuan Alam, Universitas Islam Bandung yang telah 
menyediakan semua fasilitas dalam melaksanakan penelitian ini.

\section{DAFTAR PUSTAKA}

Aertgeerts, K., Skene, R., Yano, J., Sang, B. C., Zou, H., Snell, G., Jennings, A., Iwamoto, K., Habuka, N., Hirokawa, A., Ishikawa, T., Tanaka, T., Miki, H., Ohta, Y., \& Sogabe, S. (2011). Structural analysis of the mechanism of inhibition and allosteric activation of the kinase domain of HER2 protein. Journal of Biological Chemistry, 286(21): 18756-18765.

Benet, L. Z., Hosey, C. M., Ursu, O., \& Oprea, T. I. (2016). BDDCS, the Rule of 5 and drugability. In Advanced Drug Delivery Reviews, 101: 89-98.

Berdan, C. A., Ho, R., Lehtola, H. S., To, M., Hu, X., Huffman, T. R., Petri, Y., Altobelli, C. R., Demeulenaere, S. G., Olzmann, J. A., Maimone, T. J., \& Nomura, D. K. (2019). Parthenolide Covalently Targets and Inhibits Focal Adhesion Kinase in Breast Cancer Cells. Cell Chemical Biology, 26(7): 1027-1035.

BP Basuki. (2015). Dasar-dasar Urologi. In Revue medicale suisse, 11: 456-457.

Chen, X., Li, H., Tian, L., Li, Q., Luo, J., \& Zhang, Y. (2020). Analysis of the Physicochemical Properties of Acaricides Based on Lipinski's Rule of Five. Journal of Computational Biology, 27(9): 1397-1406.

Darusman, F., Fakih, T. M., \& Nurfarida, G. F. (2021). Identification of the Glimepiride and Metformin Hydrochloride Physical Interaction in Binary Systems. Borneo Journal of Pharmacy, 4(2): 110-116.

Day, W. C., Agency, I., Day, W. C., Atomic, I., \& Agency, E. (2021). Breast cancer now most common form of cancer: WHO taking action. World Health Organization, December 2020.

Fakih, T. M., Arumsari, A., Dewi, M. L., Hazar, N., \& Syarza, T. M. (2021). Identifikasi Mekanisme Molekuler Senyawa Ftalosianina sebagai Kandidat Photosensitizer pada Terapi Fotodinamika secara In Silico. ALCHEMY Jurnal Penelitian Kimia, 17(1): 37-42.

Gyebi, G. A., Ogunro, O. B., Adegunloye, A. P., Ogunyemi, O. M., \& Afolabi, S. O. (2021).
Potential inhibitors of coronavirus 3chymotrypsin-like protease (3CLpro): an in silico screening of alkaloids and terpenoids from African medicinal plants. Journal of Biomolecular Structure and Dynamics, 39(9): 1-13.

Haslam, A., \& Prasad, V. (2019). Estimation of the percentage of us patients with cancer who are eligible for and respond to checkpoint inhibitor immunotherapy drugs. In JAMA Network Open, 2(5): e192535.

Hirota, M., Ashikaga, T., \& Kouzuki, H. (2018). Development of an artificial neural network model for risk assessment of skin sensitization using human cell line activation test, direct peptide reactivity assay, KeratinoSens ${ }^{\mathrm{TM}}$ and in silico structure alert parameter. Journal of Applied Toxicology, 38(4): 514-526.

Johnson, S. C., Dweck, C. S., Chen, F. S., Stern, H. L., Ok, S. J., \& Barth, M. (2010). At the intersection of social and cognitive development: Internal working models of attachment in infancy. Cognitive Science, 34(5): 807-825.

Kemmish, H., Fasnacht, M., \& Yan, L. (2017). Fully automated antibody structure prediction using BIOVIA tools: Validation study. PLOS ONE, 12(5): e0177923.

Kontoyianni, M., McClellan, L. M., \& Sokol, G. S. (2004). Evaluation of Docking Performance: Comparative Data on Docking Algorithms. Journal of Medicinal Chemistry, 47(3): 558-565.

Li, L., Yue, G. G. L., Lee, J. K. M., Wong, E. C. W., Fung, K. P., Yu, J., Lau, C. B. S., \& Chiu, P. W. Y. (2017). The adjuvant value of Andrographis paniculata in metastatic esophageal cancer treatment - From preclinical perspectives. Scientific Reports, 7(1): 854.

Mahanthesh, M. ., Ranjith, D., Yaligar, R., Jyothi, R., Narappa, G., \& Ravi, M. (2020). Swiss ADME prediction of phytochemicals present in Butea monosperma (Lam.) Taub. Journal of Pharmacognosy and Phytochemistry, 9(3): 1799-1809.

Motaparthi, K., Stanisic, V., Van Voorhees, A. S., Lebwohl, M. G., \&Hsu, S. (2014). From the medical board of the national psoriasis foundation: Recommendations for 
screening for hepatitis B infection prior to initiating anti-tumor necrosis factoralfa inhibitors or other immunosuppressive agents in patients with psoriasis. Journal of the American Academy of Dermatology, 70(1): 178186.

Norel, R., Sheinerman, F., Petrey, D., \& Honig, B. (2008). Electrostatic contributions to protein-protein interactions: Fast energetic filters for docking and their physical basis. Protein Science, 10(11): 2147-2161.

Petit, J., Meurice, N., Kaiser, C., \& Maggiora, G. (2012). Softening the Rule of Five Where to draw the line? Bioorganic and Medicinal Chemistry, 20(18): 5343-5351.

Priani, S. E., \& Fakih, T. M. (2021). Studi Interaksi Molekular Senyawa Hesperidin dan Nobiletin dari Kulit Buah Jeruk terhadap Enzim Tyrosinase secara In Silico. Jurnal IImiah Farmasi Farmasyifa, 4(1): 17-24.

Qasaymeh, R. M., Rotondo, D., Oosthuizen, C. B., Lall, N., \& Seidel, V. (2019). Predictive binding affinity of plant-derived natural products towards the protein kinase $g$ enzyme of mycobacterium tuberculosis (Mtpkng). Plants, 8(11): 477.
Ramadhan, D. S. F., Fakih, T. M., \& Arfan, A. (2020). Activity Prediction of Bioactive Compounds Contained in Etlingera elatior Against the SARS-CoV-2 Main Protease: An In Silico Approach. Borneo Journal of Pharmacy, 3(4): 235-242.

Tanbin, S., Fuad, F. A. A., \& Hamid, A. A. A. (2021). Virtual screening for potential inhibitors of human hexokinase ii for the development of anti-dengue therapeutics. In High-Throughput, 10(1): 1.

Wang, Z., Mori, K., Nakajima, K., \& Narita, F. (2020). Fabrication, modeling and characterization of magnetostrictive short fiber composites. Materials, 13(7): 1494.

Yoshimoto, S., Kato, D., Kamoto, S., Yamamoto, K., Tsuboi, M., Shinada, M., Ikeda, N., Tanaka, Y., Yoshitake, R., Eto, S., Saeki, K., Chambers, J., Hashimoto, Y., Uchida, K., Nishimura, R., \& Nakagawa, T. (2020). Overexpression of human epidermal growth factor receptor 2 in canine primary lung cancer. Journal of Veterinary Medical Science, 82(6): 804808. 